\title{
DEVELOPMENT OF SCIENTIFIC AND INFORMATIVE POTENTIAL OF STUDENTS IN THE TEACHING OF THE INVERSE PROBLEMS FOR DIFFERENTIAL EQUATIONS
}

\author{
V.S. Kornilov \\ Moscow City Pedagogical University \\ Sheremetjevskaya str., 29, Moscow, Russia, 127521
}

In article attention that when training in the inverse problems for differential equations at students scientific and cognitive potential develops is paid. Students realize that mathematical models of the inverse problems for differential equations find the application in economy, the industries, ecology, sociology, biology, chemistry, mathematician, physics, in researches of the processes and the phenomena occurring in water and earth's environment, air and space.

Attention of the reader that in training activity to the inverse problems for differential equations at students the scientific outlook, logical, algorithmic, information thinking, creative activity, independence and ingenuity develop is focused. Students acquire skills to apply knowledge of many physical and mathematical disciplines, to carry out the analysis of the received decision of the reverse task and to formulate logical outputs of application-oriented character. Solving the inverse problems for differential equations, students acquire new knowledge in the field of applied and calculus mathematics, informatics, natural sciences and other knowledge.

Key words: training in the inverse problems for differential equations, the scientific and cognitive potential of students, mathematical simulation, applied mathematics

For over half a century in Russia and abroad, actively developing the theory of inverse problems for differential equations, one of the scientific fields of applied mathematics. A great contribution to its development is made by A.V. Baev, P.N. Vabishevich, A.O. Vatulyan, V.V. Vasin, A.M. Denisov, S.I. Kabanikhin, M.M. Lavrentiev, D.G. Orlovsky, A.I. Prilepko, V.G. Romanov, A.N. Tikhonov, V.A. Cheverda, V.G. Cherednichenko, V.A. Yurko, A.G. Yagola and other authors (see for example [1-3; 5; 17-19]). Using the methods of the theory of inverse problems for differential equations successfully explores a variety of processes and phenomena, reveal their causation.

Note some of the scientific area where the application of the theory of inverse problems for differential equations.

1. The problem of studying the Earth's interior using geophysical methods, based on the study of the earth's surface any of the physical field, carrying information on the deep structure of the Earth, having as theoretical importance to global Geophysics, and of great practical significance for mineral exploration. Such problems belong to inverse problems of Geophysics.

2. The study of the nature of elastic oscillations of the Earth observed data. Despite the diversity of the elastic fields they carry information about the properties of their 
sources and on the structure of the earth through which seismic wave propagates. The task of studying such objects in the observed fields related to the problems of seismology and are inverse problems of seismology.

3. The problem of Maritime natural disasters, waves-flood type, tsunami caused by underwater earthquakes, landslides, explosions, underwater volcanoes. The inverse problem of marine natural disasters are the defining characteristics of these waves in the deep area close to island records mareographic station.

4. The creation of diagnostic devices that combine the possibility of collecting a very large number of angles, with a processing computer means. This, in particular, CT scanner, designed for diagnostics and non-destructive quality control of products and used in various fields: medicine, biology, chemistry, Geophysics etc. are of Decisive importance in the design and creation of computer tomography is the mathematical modeling of tomographybased. On the basis of this simulation program are the reconstruction images of the studied objects. Thus, in the basis of computer tomography is based on the theory of direct and inverse problems.

5. To solve the problem of controlled thermonuclear synthesis it is necessary to know the regularities of heating and plasma confinement in fusion devices. Identifying these patterns requires detailed information about the development of the discharge and plasma parameters. In modern installations, the temperature of the plasma measured in millions of degrees. No direct measurements inside a hot environment is impossible. So all the information about the plasma it is necessary to obtain on the basis of indirect measurements performed outside the plasma, and the subsequent solution of the corresponding mathematical problems and their implementation by computer means. These tasks relate to the inverse problems of plasma diagnostics.

6. The processing of photos, including the problem of image restoration (removal of scratches on the image, changing image contrast, etc. - and some processing elements increasing the visual informativeness of the frame), restoring blurry and defocused images. Tasks of image processing are reverse to the tasks of processing photographic images.

7. Planning and processing of experimental data engineering, economic optimal control problems. Similar problems are studied with variational methods for solving inverse problems.

Inverse problems for differential equations are also applied in the economy, industry, ecology, sociology, biology, chemistry, mathematics, physics, to study the processes and phenomena occurring in aquatic and terrestrial environment, air and outer space.

Thus, many applied studies in which the final word is experiment, faced with the solution of inverse problems for differential equations, representing the unity of theory and experiment that are relevant to all three methods of human cognition: theory, experiment and philosophy.

Given the wide practical importance of the theory of inverse problems for differential equations, some Russian universities for students of physical and mathematical science training areas taught in elective courses devoted to inverse problems for differential equations (see, e.g., [1-19]).

In the process of learning the inverse problems for differential equations, implemented ideas for the development of creative mathematical abilities of students. In the research process, learning the inverse problems for differential equations require students to 
skillfully apply the knowledge of various methods of applied and computational mathematics that they were taught in courses of mathematical, functional, vector analysis, analytic geometry, algebra, integral equations and other courses. However, given the applied aspects and mathematical features of inverse and ill-posed problems, require students to independently implement a variety of creative solutions for the proof of corresponding theorems of existence, uniqueness and conditional stability of solutions to inverse problems. During the study of inverse problems for differential equations, students have realized to operate with such fundamental concepts of applied and computational mathematics, as conditional correctness of the mathematical models, causation of physical processes and phenomena, pulsed sources, initiating physical processes discretization of mathematical models, convergence and stability of solution of a differential inverse problem and other fundamental concepts..In the process of learning the inverse problems for differential equations, implemented ideas for the development of creative mathematical abilities of students. In the research process, learning the inverse problems for differential equations require students to skillfully apply the knowledge of various methods of applied and computational mathematics that they were taught in courses of mathematical, functional, vector analysis, analytic geometry, algebra, integral equations and other courses. However, given the applied aspects and mathematical features of inverse and ill-posed problems, require students to independently implement a variety of creative solutions for the proof of corresponding theorems of existence, uniqueness and conditional stability of solutions to inverse problems. During the study of inverse problems for differential equations, students have realized to operate with such fundamental concepts of applied and computational mathematics, as conditional correctness of the mathematical models, causation of physical processes and phenomena, pulsed sources, initiating physical processes discretization of mathematical models, convergence and stability of solution of a differential inverse problem and other fundamental concepts.

Realization of intersubject communications when training in the inverse problems for the differential equations allows students not only to create fundamental knowledge in the field of the theory and methodology of the inverse problems, to gain skills of use of mathematical methods of a research of physical processes, the qualitative analysis of their decisions, to develop scientific outlook and mathematical creative abilities, but also to fill up the knowledge in the field of such scientific concepts of informatics as information, modeling, formalization, algorithmization, a computing experiment, syntax, semantics and other scientific concepts of informatics, to comprehend their value and a role in knowledge of the world around.

When training in the inverse problems for differential equations data that mathematical models of the inverse problems are an effective method of knowledge of the world around, and also prediction and control are brought to the attention of students and allow to penetrate into an entity of the researched processes and the phenomena. In case of such training students seize not only the theory and methodology of the inverse and incorrect problems, but acquire fundamental knowledge in the field of applied and calculus mathematics, other knowledge domains which allows them to comprehend and apply the principles of the organization of theoretical and practical researches of the inverse problems for differential equations. We will mark some of them. 
1. Principle of interdisciplinary approach. The idea of this principle - multiconcreteness of the description of integral processes and the phenomena on the knowledge base from different scientific areas.

2. Principle of structurally functional and dynamic unity. This principle obliges to the description of laws of objects, functioning and development in their unity, and requires a research of processes, the phenomena or objects in all their diversity. It promotes an explanation of processes of formation of the phenomena, disclosure of character and content of behavior of this phenomenon or process.

3. Principle of a multilevelness. This principle urges to study an object and as a certain integrity and as the education switched on in more difficult system. Its use allows to research the general features and single lines of an object. In case of the multi-level description of system each of levels can be in turn broken into a row of subtotals. The quantity of these subtotals reflects penetration depth in an entity of the researched process or the phenomenon in each level.

4. Principle of causes and effect relationships. It is the basic principle which requires a deep study of the causes and effect relationships connected to the direction of the causeeffect course of events and the phenomena. It allows to recover unknown properties of the studied objects. At the same time the technology of achievement of integrity of knowledge includes not only use of a certain set of methods of a research of the inverse problems for differential equations, but also generalizations of the gained applicationoriented knowledge in a uniform scientific pattern, clearings up of opportunities and practical application of the received results of researches of the reverse tasks. Such approach to a research of the inverse problems for differential equations promotes realization by students of interpenetration and mutual enrichment of the scientific methods, approaches and receptions developed in different knowledge domains.

The independent research students of various inverse problems for differential equations on the basis of knowledge in the field of the theory and methodology of the reverse and incorrect tasks, implementation not only the known methods of applied and calculus mathematics, but also own approaches and the ideas promotes their creative development and formation in them of application-oriented mathematical thinking. Proving difficult existence theorems, uniqueness and the conditional stability of the decision of various inverse problems for differential equations, students comprehend physical aspects of the application-oriented task, reveal causes and effect relationships, study to formulate logical outputs of application-oriented and humanitarian character by results of the conducted researches.

In the course of such training at students the scientific outlook, logical, algorithmic, information thinking, creative activity, independence and ingenuity develop. Students acquire skills to apply knowledge of many physical and mathematical disciplines, to carry out the analysis of the received decision of the reverse task and to formulate logical outputs of application-oriented character. Solving educational reverse problems for differential equations, students not only master the theory and practice of the reverse tasks, methodology of a research of application-oriented tasks, acquire new knowledge in the field of applied and calculus mathematics, but, obviously, develop also a mathematical intuition. 
Existence of the mathematical intuition which is based on fundamental knowledge in the field of applied and calculus mathematics, the theory and methodology of the inverse problems for differential equations, experience of a successful research of the reverse tasks allows students to realize the rational ideas allowing to research and find successfully solutions of various inverse problems. The mathematical intuition helps students to comprehend a physical sense of the researched application-oriented task, to select a successful mathematical apparatus, to plan a rational way of a research of a mathematical model of the reverse task, and, eventually, successfully to find its solution.

When training in the inverse problems for differential equations data that mathematical models of the reverse tasks are an effective method of knowledge of the world around, and also prediction and control are brought to the attention of students and allow to penetrate into an entity of the studied phenomena. On the basis of the analysis of the received decisions, students are convinced that decisions of the inverse problems for differential equations can give new scientific knowledge, having replaced direct measurements while decisions of direct tasks which are predetermined by the most mathematical model and the given influences, don't give new information on the studied phenomenon if external influences are studied.

\section{LITERATURE}

[1] Ватульян А.О., Беляк О.А., Сухов Д.Ю., Явруян О.В. Обратные и некорректные задачи: учеб. пособие. Ростов-н/Д: Изд-во Южного федерального университета, 2011. 232 с.

[2] Денисов А.М. Введение в теорию обратных задач: учеб. пособие. М.: Изд-во МГУ им. М.В. Ломоносова, 1994. 207 с.

[3] Кабанихин С.И. Обратные и некорректные задачи: учеб. пособие. Новосибирск: Сибирское научное издательство, 2009. 458 с.

[4] Корнилов B.C. О междисциплинарном характере исследований причинно-следственных обратных задач // Вестник Московского городского педагогического университета. Серия «Информатика и информатизация образования». 2004. № 1 (2). С. $80-83$.

[5] Корнилов B.C. Некоторые обратные задачи идентификации параметров математических моделей: учеб. пособие. М.: МГПУ, 2005. 359 с.

[6] Корнилов B.C. Основы методической системы обучения дисциплине «Обратные задачи для дифференциальных уравнений» // Вестник Самарского государственного экономического университета. 2005. № 3 (18). С. 190-196.

[7] Корнилов B.C. Вузовская подготовка специалистов по прикладной математике - история и современность // Наука и школа. 2006. № 4. С. 10-12.

[8] Корнилов B.C. Обучение обратным задачам для дифференциальных уравнений как фактор гуманитаризации математического образования: монография. М.: МГПУ, 2006. 320 с.

[9] Корнилов B.C. Гуманитарные аспекты вузовской системы прикладной математической подготовки // Наука и школа. 2007. № 5. С. 23-28.

[10] Корнилов В.С. Обратные задачи в учебных дисциплинах прикладной математики // Вестник Московского городского педагогического университета. Серия «Информатика и информатизация образования». 2014. № 1 (27). С. 60-68.

[11] Корнилов В.С. Формирование фундаментальных знаний будущих учителей информатики и математики по функциональному анализу при обучении обратным задачам математической физики // Вестник Московского городского педагогического университета. Серия «Информатика и информатизация образования». 2015. № 3 (33). С. 72-82.

[12] Корнилов B.C. Обучение студентов обратным задачам математической физики как фактор формирования фундаментальных знаний по интегральным уравнениям // Бюллетень лаборатории математического, естественнонаучного образования и информатизации. 
Рецензируемый сборник научных трудов. Самара: Самарский филиал МГПУ, 2015. Том VI. C. $251-257$.

[13] Корнилов B.C. Реализация методов вычислительной математики при обучении студентов обратным задачам для дифференциальных уравнений // Вестник Московского городского педагогического университета. Серия «Информатика и информатизация образования». 2016. № 2 (36). С. 91-100.

[14] Корнилов B.C. Реализация научно-образовательного потенциала обучения студентов вузов обратным задачам для дифференциальных уравнений // Казанский педагогический журнал. 2016. № 6. С. 55-59.

[15] Корнилов B.C. Реализация учебно-воспитательных функций в обучении обратным задачам для дифференциальных уравнений // Альманах мировой науки. 2016. № 5-2 (8). С. 6364.

[16] Корнилов B.C. Теория и методика обучения обратным задачам для дифференциальных уравнений: монография. М.: Изд-во «ОнтоПринт», 2017. 500 с.

[17] Романов В.Г. Обратные задачи математической физики: монография. М.: Наука, 1984. $264 \mathrm{c}$.

[18] Самарский А.А., Вабишевич П.Н. Численные методы решения обратных задач математической физики: монография. М.: УРСС, 2004. 478 с.

[19] Сизиков B.C. Обратные прикладные задачи и MatLab: учеб. пособие. СПб.: Лань, 2011. $251 \mathrm{c}$.

(C) Kornilov V.S., 2017

Article history:

Received: 20 January, 2017

Accepted: 28 February, 2017

For citation:

Kornilov V.S. (2017) Development of scientific and informative potential of students in the teaching of the inverse problems for differential equations. RUDN Journal of Informatization Education, 14 (2), 205-212.

\title{
Bio Note:
}

Kornilov Viktor Semenovich, doctor of pedagogical sciences, candidate of physical and mathematical sciences, full professor, deputy head of the department of informatization of education of the Moscow city pedagogical university.

Contact information: e-mail: vs_kornilov@mail.ru.

\section{РАЗВИТИЕ НАУЧНО-ПОЗНАВАТЕЛЬНОГО ПОТЕНЦИАЛА СТУДЕНТОВ ПРИ ОБУЧЕНИИ ОБРАТНЫМ ЗАДАЧАМ ДЛЯ ДИФФЕРЕНЦИАЛЬНЫХ УРАВНЕНИЙ}

\author{
В.С. Корнилов \\ Московский городской педагогический университет \\ Шереметьевская ул., 29, Москва, Россия, 127521
}

В статье обращается внимание на то, что при обучении обратным задачам для дифференциальных уравнений у студентов развивается научно-познавательный потенциал. Студенты осознают, что математические модели обратных задач для дифференциальных уравнений на- 
ходят свое применение в экономике, промышленности, экологии, социологии, биологии, химии, математике, физике, в исследованиях процессов и явлений, происходящих в водной и земной среде, воздушном и космическом пространстве.

Акцентируется внимание читателя на то, что в процессе обучения обратным задачам для дифференциальных уравнений у студентов развиваются научное мировоззрение, логическое, алгоритмическое, информационное мышление, творческая активность, самостоятельность и сообразительность. Студенты приобретают умения и навыки применять знания по многим физико-математическим дисциплинам, проводить анализ полученного решения обратной задачи и формулировать логические выводы прикладного характера. Решая обратные задачи для дифференциальных уравнений, студенты приобретают новые знания в области прикладной и вычислительной математики, информатики, естествознания и другие знания.

Ключевые слова: обучение обратным задачам для дифференциальных уравнений, научнопознавательный потенциал студентов, математическое моделирование, прикладная математика

\section{REFERENCES}

[1] Vatulyan A.O., Belyak O.A., Sukhov D.Yu., Yavruyan O.V. Obratnye i nekorrektnye zadachi [Inverse and incorrect tasks]: ucheb. posobie. Rostov-na-Donu: Izd-vo Juzhnogo federal'nogo universiteta, 2011. $232 \mathrm{p}$.

[2] Denisov A.M. Vvedenie v teoriju obratnyh zadach [Introduction to the theory of the inverse problems]: ucheb. posobie. M.: Izd-vo MGU im. M.V. Lomonosova, 1994. 207 p.

[3] Kabanihin S.I. Obratnye i nekorrektnye zadachi [Inverse and incorrect tasks]: uchebnik dlja studentov vuzov. Novosibirsk: Sibirskoe nauchnoe izdatel'stvo, 2009. 458 p.

[4] Kornilov V.S. O mezhdisciplinarnom haraktere issledovanij prichinno-sledstvennyh obratnyh zadach [About cross-disciplinary character of researches of cause and effect inverse problems] // Vestnik Moskovskogo gorodskogo pedagogicheskogo universiteta. Serija «Informatika i informatizacija obrazovanija» [Bulletin of the Moscow city pedagogical university. "Informatics and Informatization of Education" series]. 2004. No. 1 (2). Pp. 80-83.

[5] Kornilov V.S. Nekotorye obratnye zadachi identifikacii parametrov matematicheskih modelej [Some inverse problems of identification of parameters of mathematical models]: ucheb. posobie. M.: MGPU, 2005. $359 \mathrm{p}$.

[6] Kornilov V.S. Osnovy metodicheskoj sistemy obuchenija discipline «Obratnye zadachi dlja differencial'nyh uravnenij» [Bases of methodical system of training in discipline "The inverse problems for the differential equations"] // Vestnik Samarskogo gosudarstvennogo jekonomicheskogo universiteta [Bulletin of the Samara state economic university]. 2005. No. 3 (18). Pp. 190-196.

[7] Kornilov V.S. Vuzovskaja podgotovka specialistov po prikladnoj matematike - istorija i sovremennost' [High school training of specialists on applied mathematics - history and the present]. Nauka $i$ shkola [Science and school]. 2006. No. 4. Pp. 10-12.

[8] Kornilov V.S. Obuchenie obratnym zadacham dlja differencial'nyh uravnenij kakfaktorgumanitarizacii matematicheskogo obrazovanija [Training in the inverse problems for the differential equations as a factor of humanitarization of mathematical education]: monografiya. M.: MGPU, 2006. $320 \mathrm{p}$.

[9] Kornilov V.S. Gumanitarnye aspekty vuzovskoj sistemy prikladnoj matematicheskoj podgotovki [Humanitarian aspects of high school system of applied mathematical preparation]. Nauka $i$ shkola [Science and school]. 2007. No. 5. Pp. 23-28.

[10] Kornilov V.S. Obratnye zadachi v uchebnyh disciplinah prikladnoj matematiki [The inverse problems in subject matters of applied mathematics] // Vestnik Moskovskogo gorodskogo pedagogicheskogo universiteta. Serija «Informatika i informatizacija obrazovanija» [Bulletin of the Moscow city pedagogical university. "Informatics and Informatization of Education” series]. 2014. № 1 (27). Pp. 60-68.

[11] Kornilov V.S. Formirovanie fundamental'nyh znanij budushhih uchitelej informatiki i matematiki po funkcional'nomu analizu pri obuchenii obratnym zadacham matematicheskoj fiziki [Formation of fundamental knowledge of future teachers of informatics and mathematics of the functional 
analysis when training in the inverse problems of mathematical physics]. Vestnik Moskovskogo gorodskogo pedagogicheskogo universiteta. Serija «Informatika i informatizacija obrazovanija» [Bulletin of the Moscow city pedagogical university. "Informatics and Informatization of Education" series]. 2015. No. 3 (33). Pp. 72-82.

[12] Kornilov V.S. Obuchenie studentov obratnym zadacham matematicheskoj fiziki kak factor formirovanija fundamental'nyh znanij po integral'nym uravnenijam [Training of students in the inverse problems of mathematical physics as factor of formation of fundamental knowledge of the integrated equations]. Bjulleten' laboratorii matematicheskogo, estestvennonauchnogo obrazovanija i informatizacii. Recenziruemyj sbornik nauchny trudov [Bulletin of laboratory of mathematical, natural-science education and informatization. The reviewed collection of scientific work]. Samara: Samarskij filial MGPU, 2015. T. VI. Pp. 251-257.

[13] Kornilov V.S. Realizacija metodov vychislitel'noj matematiki pri obuchenii studentov obratnym zadacham dlja differencial'nyh uravnenij [Realization of methods of calculus mathematics when training students in the inverse problems for the differential equations]. Vestnik Moskovskogo gorodskogo pedagogicheskogo universiteta. Serija «Informatika i informatizacija obrazovanija» [Bulletin of the Moscow city pedagogical university. "Informatics and Informatization of Education" series]. 2016. No. 2 (36). Pp. 91-100.

[14] Kornilov V.S. Realizacija nauchno-obrazovatel'nogo potenciala obuchenija studentov vuzov obratnym zadacham dlja differencial'nyh uravnenij [Realization of scientific and educational potential of training of students of higher education institutions in the inverse problems for the differential equations]. Kazanskij pedagogicheskij zhurnal [Kazan pedagogical journal]. 2016. No. 6. Pp. 5559.

[15] Kornilov V.S. Realizacija uchebno-vospitatel'nyh funkcij v obuchenii obratnym zadacham dlja differencial'nyh uravnenij [Realization of teaching and educational functions in training in the return tasks for the differential equations] // Al'manah mirovoj nauki [Almanac of world science]. 2016. No. 5-2 (8). Pp. 63-64.

[16] Kornilov V.S. Teorija i metodika obuchenija obratnym zadacham dlja differencial'nyh uravnenij [Theory and technique of training to the inverse problems for differential equations]: monografija. M.: Izd-vo «OntoPrint», 2017. 500 p.

[17] Romanov V.G. Obratnye zadachi matematicheskojfiziki [Inverse problems of mathematical physics]: monografija. M.: Nauka, 1984. 264 p.

[18] Samarskij A.A., Vabishevich P.N. Chislennye metody reshenija obratnyh zadach matematicheskoj fiziki [Numerical methods of the solution of the inverse problems of mathematical physics]: monografija. M.: Editorial URSS, 2004. 480 p.

[19] Sizikov V.S. Obratnye prikladnye zadachi i MatLab [Return applied tasks and MatLab]: ucheb. posobie. SPb.: Lan', 2011. 251 p.

\section{История статьи:}

Дата поступления в редакцию: 20 января 2017

Дата принятия к печати: 28 февраля 2017

\section{Для цитирования:}

Корнилов В.С. Развитие научно-познавательного потенциала студентов при обучении обратным задачам для дифференциальных уравнений // Вестник Российского университета дружбы народов. Серия «Информатизация образования». 2017. Т. 14. № 2. С. 205-212.

\section{Сведения об авторе:}

Корнилов Виктор Семенович, доктор педагогических наук, кандидат физико-математических наук, профессор, заместитель заведующего кафедрой информатизации образования Московского городского педагогического университета.

Контактная информация: e-mail: vs_kornilov@mail.ru 